\title{
Językowy obraz śmierci w tekstach piosenek metalowych z lat osiemdziesiątych XX wieku - wybrane zagadnienia
}

Choć śmierć jest zjawiskiem, które towarzyszy wszystkim istotom żywym, uchodzi za jedną z największych zagadek istnienia. Nic więc dziwnego, iż na kwestię tę silny nacisk kładą niemal wszystkie systemy filozoficzne i religie świata, które zazwyczaj traktują śmierć jedynie jako swoisty etap przejścia, np. przed zmartwychwstaniem bądź przed odrodzeniem się w innej postaci (vide: reinkarnacja). Motyw śmierci jest także przedmiotem rozważań wielu pisarzy i poetów. Szczególnie zaznaczył się on w dobie średniowiecza. Wówczas najprawdopodobniej ukształtował się prototypowy wizerunek śmierci (kościotrup z kosą, przyodziany w płaszcz z kapturem). W baroku sięgano po motywy wanitatywne, podkreślając kruchość jednostki ludzkiej, jej marność. Wątek ten odżył w modernizmie. Dodatkowo doszły do niego fascynacje rozkładem i siłami nieczystymi. Wszystkie te elementy złożyły się na specyficzną konceptualizację śmierci w tekstach piosenek metalowych, o czym świadczą przeprowadzone badania leksykalne.

Subkultura metalowa powstała w latach siedemdziesiątych XX w. Swój ostateczny kształt zyskała w następnej dekadzie. Na powstanie ruchu złożyły się przede wszystkim dwa czynniki: po pierwsze, załamanie się kontrkulturowej fazy w rozwoju kultury młodzieżowej w Europie i USA, czemu towarzyszyła teatralizacja koncertów rockowych oraz, po drugie, odrzucenie przez młodzież stylu disco, przy jednoczesnym powrocie do ikon ostrego rocka. Przedstawiciele tej subkultury swą odrębność podkreślają specyficznym wyglądem. Składają się na niego długie włosy, nabijane ćwiekami kurtki i pasy, symbolika militarna oraz tatuaże. Kolorem dominującym w ubiorze jest czarny [Pęczak 1992: 53-54; Prejs 2005: 54]. Marek Zawadzki dostrzega, że teksty tworzone przez grupy metalowe mówią przeważnie o imponderabiliach życia codziennego, etosie rycerskim, okultyzmie, magii, fizycznym rozkładzie ciała oraz o dobroci i miłości chrześcijańskiego Boga [Zawadzki 2005: 191-192]. 
Badania frekwencyjne dowodzą, że w językowym obrazie świata ${ }^{1}$, który możemy odtworzyć z tekstów piosenek metalowych powstałych w latach osiemdziesiątych XX w. ${ }^{2}$, śmierć pełni szczególną rolę. Leksem ŚMIERĆ występuje w nich 265 razy, tym samym plasując się na pierwszym miejscu pośród najczęstszych rzeczowników w zgromadzonym korpusie tekstowym. Przypomnijmy, że frekwencja stanowi ważne narzędzie, służebne wobec badań nad językowym obrazem świata. Warto nadmienić, że tak częste występowanie wyżej wymienionego leksemu nie obejmuje wszystkich możliwych ujęć interesującego nas zjawiska. To, że dany fragment piosenki mówi o śmierci, często wynika z kontekstu.

Rekonstrukcja językowego obrazu śmierci prowadzi do wyodrębnienia kilku faset $^{3}$, które składają się na prototypowy obraz omawianego zjawiska. Tworzą one swego rodzaju profil animizacyjno-personifikacyjny, który wynika ze specyficznej konceptualizacji śmierci w badanym materiale. Najczęściej śmierć bywa ujmowana jako istota żywa, także o cechach ludzkich. Ma zdolność poruszania się, mówienia, wpływania na innych, posiada również dłonie oraz oczy. Niekiedy jest obrazowana jako istota żywa przybyła spoza Ziemi (np. zjawa), która dysponuje mocą większą od człowieka (np. zabiera życie, przebywa w obecności sił nieczystych).

Rekonstruując obraz śmierci, spróbujmy odpowiedzieć na pytanie, KIM JEST oraz CZYM JEST śmierć. Analiza tekstów piosenek dowodzi, że ŚMIERĆ TO ISTOTA ŻYWA. Oto przykłady: „Z otchłani piekła żywa śmierć wyciąga dłoń swą i szepcze Chodź!!!" (Oddech Buntownika, Już tu nie wrócisz szatanie)"; „W łonie żywej śmierci Szatana syn” (Oddech Buntownika, Krew i tzy). Skoro jest ŻYWA, może wykonywać szereg czynności, które przysługują ludziom, por: „Oddech śmierci, ludzie biegną w żar” (Dragon, Siedem czar gniewu); „Grobu chłód / Śmierci glos” (Vader, Satans Wrath); „Śmierć nadchodzi, powoli zbliża się" (Hellias, Noc potępienia). Przytoczone cytaty dowodzą, że śmierć posiada zdolność oddychania, mówienia, chodzenia, a zatem przymioty typowe dla żywej jednostki ludzkiej.

${ }^{1}$ Za Renatą Grzegorczykową przyjmujemy, że językowy obraz świata należy traktować ,„[...] jako strukturę pojęciową utrwaloną (zakrzepłą) w systemie danego języka, a więc jego właściwościach gramatycznych i leksykalnych [...], realizującą się, jak wszystko w języku, za pomocą tekstów (wypowiedzi)" [Grzegorczykowa 2004: 41].

${ }^{2}$ Na materiał badawczy złożyło się ok. 280 tekstów piosenek tworzonych przez zespoły metalowe w dziewiątej dekadzie XX w. Badaniem objęto jedynie polskojęzyczne utwory (bądź ich tłumaczenia na język polski). Przez termin „teksty piosenek metalowych” rozumiemy te teksty, które pisane były przez grupy muzyczne reprezentujące różne odmiany metalu, np. heavy metal i thrash metal.

${ }^{3}$ Nazwy niektórych faset (np. wygląd, właściwości) zaczerpnięto ze Stownika stereotypów i symboli ludowych [por. Bartmiński 1996].

${ }^{4}$ Wszystkie pogrubienia pochodzą od autorki niniejszego artykułu. Większość zacytowanych fragmentów tekstów zaczerpnięto ze stron http://www.metal-archives.com/, http://www.metallyrica.com/, http://teksty.org/, z oficjalnych stron zespołów bądź bezpośrednio od członków formacji metalowych i ich fanów, za co serdecznie dziękuję. 
To, kim jest śmierć, możemy bardziej doprecyzować. Z tekstów piosenek wyłania się obraz śmierci jako MATKI i KOCHANKI: „Na pokładzie czarna śmierć / Matka Króla bez litości / Która zawsze przy nim jest" (Magnus, Czarny aniot); „W lonie żywej śmierci Szatana syn” (Oddech Buntownika, Krew i łzy). W podanych przykładach widzimy typowe dla muzyki metalowej zainteresowanie motywem szatana. Z jednej strony śmierć traktowana jest jako nieodłączna towarzyszka diabła, wybierająca się z nim po ludzkie dusze, z drugiej bywa konceptualizowana jako KOCHANKA szatana, bowiem w jej łonie rozwija się potomek diabła. Ujmowana bywa także metaforycznie jako CÓRKA, w połączeniu wyrazowym „rodzić śmierć”, por.: „Miłość rodzi śmierć” (Destroyers, Wino i sex). Konotacje miłosne widzimy także we fragmencie ujmującym śmierć jako NARZECZONĄ. Porównajmy: „zjawia się to jest właśnie ona / pani twa piękna narzeczona” (Kreon, Śmierć). Interesujący jest wizerunek śmierci jako KAPITANA: „Płynie wielki galeon, / Poganiany przez śmierć” (Turbo, Żotnierz fortuny). Przykład ten dowodzi mocnego zakotwiczenia tekstów metalowych w kulturze. Zgodnie ze słownikiem symboli, okręt bądź statek symbolizuje m.in. śmierć [Kopaliński 2012: 274]. Niejednokrotnie przekonamy się, że leksyka występująca w badanym materiale ma ścisły związek z pojęciami wyrosłymi z Biblii, a zatem z prapoczątkami naszej cywilizacji i kultury. Dowodzi tego przykład, w którym śmierć porównana zostaje do APOSTOŁA: „,́mierć jest jak apostoł zjawia się zbiera swój plon" (Kreon, Śmierć). Choć apostołowie są w Piśmie Świętym postaciami pozytywnymi, w podanym cytacie APOSTOŁ - ŚMIERĆ zwiastuje zniszczenie, klęskę, nieuchronność. Złowieszczość i nadejście śmierci ilustruje ponadto utwór, w którym, w nieco archaicznej formie, przyrównuje się ją do GENIUSZA: „Jeniusz śmierć już idzie" (Turbo, Żotnierz fortuny). Przypisuje się jej także cechy WŁADCY: „Przed oblicze śmierci musi iść” (Egzekuthor, Egzekutor); „I z paktu śmierć za wladzę znów ma bilans dać" (Egzekuthor, Śmierci i władzy pakt).

W obrębie omawianej fasety możemy wymienić przykłady określające, CZYM JEST ŚMIERĆ. Wiele wskazuje na to, że jest ona istotą przerażającą, zbliżoną do DUCHA: „Napadła cicha, szybka jak cień / Straszliwa zjawa, okrutna śmierć” (Azzaron, Dzień zagłady); „Czy czujesz wokół śmierć, uważaj ze strony twej / płynie postać nie z tych ziem, wejdźmy w nią, złączmy się" (Thrasher Death, Przyjdź śmierć). Miejscem jej pochodzenia, a zarazem zamieszkania, może być cmentarzysko: „Tkwi zakopana gdzieś przez całe lata śmierć / Ukryta w ścianach skrzyń czeka dnia, aby wyjść” (Alastor, Dotyk przemocy); „Opuszcza swój grób” (Egzekuthor, Egzekutor), a jako niebezpiecznej ZJAWY - piekło: „Po drugiej stronie tego świata budzi się śmierć, przemoc i gwałt" (Oddech Buntownika, Ostatni dzień przed zmartwychwstaniem); „Z otchłani piekła żywa śmierć wyciąga dloń swą i szepcze Chodź!!!' (Oddech Buntownika, Już tu nie wrócisz szatanie). W pojedynczych wskazaniach śmierć konceptualizowana jest jako OWAD, bowiem posiada zdolność żądlenia jak pszczoła czy osa: „Nie zapomnij, że żądło śmierci 
- grzech" (Turbo, Salvator Mundi), ale i OTCHŁAŃ, co ciekawe, podobnie jak życie: „Życie i śmierć / Otchłań bez dna” (Azzaron, Otchtań zła). Obydwa sposoby obrazowana śmierci mają negatywne zabarwienie emocjonalne - kojarzenie śmierci z bolesnym i nieraz śmiercionośnym żądleniem bądź z bezkresną otchłanią sugeruje to w sposób jednoznaczny.

Następna faseta, WYGLĄD, stanowi konsekwencję wyżej wymienionych przykładów. Jako istota widzialna, namacalna, a nawet człekopodobna, śmierć posiada charakterystyczny wygląd. Wychodząc od ogółu, możemy przytoczyć następujące przykłady: „Napadła cicha, szybka jak cień / Straszliwa zjawa, okrutna śmierć” (Azzaron, Dzień zagłady); „Imperium zła pochłonie wszystkich, noc brudnej śmierci, noc brudnych ciał" (Oddech Buntownika, Krew i tzy). Najogólniej możemy stwierdzić, że swym wyglądem zewnętrznym śmierć wzbudza przerażenie, co również ma potwierdzenie literacko-kulturowe. Rzadszą, słabą konotacją jest stwierdzenie, że śmierć jest „brudna”. To przeciwstawienie śmierci czystości może zwiastować jej zło, związane analogicznie z nieczystością.

Przechodząc do bardziej szczegółowego opisu śmierci, zwróćmy uwagę na jej TWARZ. Jest ona groźna i przeraźliwa: „Jej twarz - grozy twarz” (Egzekuthor, Egzekutor). Nie brak również opisów OCZU, na przykład: „wielki świat już pulsuje w jej oczach pięknie lśni” (Kreon, Przeznaczenie); „Ci co poznali śmierć i jej oczu blask / Znają naszą przyszłość, nowego życia smak” (Quo Vadis, Niewinne pytania). O śmierci mówią prawdopodobnie także i te cytaty: „Biała twarz bez oczu i warg / Bezduszny śmiech śmierci wiew / Żywy trup dotyka mych ust / Wysysa krew, miażdży mózg” (Turbo, Dtoń potwora); „zaklinam cię znów widzę twoich oczu biel / chłodną biel" (Kreon, Obłęd). Na podstawie przytoczonych fragmentów możemy stwierdzić, że śmierć posiada OCZY. Autorzy tekstów przypisują im cechy „lśnienia” oraz posiadania „blasku”, co może sugerować pozytywne wartościowanie śmierci. Bywa jednak, że OCZY śmierci przerażają, konotują strach i chłód.

Śmierć wyobraża się jako istotę mającą USTA. Ciekawie i metaforycznie o USTACH mówi fragment piosenki Aids zespołu Turbo: „Aids - Słodkie usta śmierci" (Turbo, AIDS). Mowa o niezwykle groźnej chorobie, która już od kilku dekad nęka miliony ludzi. Zachorowanie na AIDS można utożsamiać z pocałunkiem śmierci, bowiem nie wynaleziono dotąd na nie leku.

Śmierć posiada również DŁONIE / RĘCE. Konceptualizuje się je na dwa sposoby. Z jednej strony, konotują one bezpieczeństwo, spokój, upragnioną bliskość: „,́mierci dłoń dotyka mnie / dusza ma szczęśliwa jest / czuję jej chłodny uścisk leciutko wtula się” (Kreon, Przeznaczenie); „Białą dłonią zamknie oczy / I otuli płaszczem snów” (Ceti, Brama tęczy). Z drugiej zaś, RĘKA / DŁOŃ śmierci wymierza sprawiedliwość lub wciąga śmiertelnika do piekła: „Z otchłani piekła żywa śmierć wyciąga dłoń swą i szepcze Chodź!!!’' (Oddech Buntownika, Już tu nie wrócisz szatanie); ,Sprawiedliwa ręka nie da szans / Przerażone twarze, któ- 
rym w oczy patrzy śmierć" (Egzekuthor, Egzekutor). Wyekscerpowane fragmenty ukazują zatem dwoistość podejścia metalowców do śmierci: z jednej strony komunikują swój strach przed nią, z drugiej zaś - fascynację.

Śmierci przypisuje się zwyczajowo dwie barwy: BIEL i CZERŃ. Kolor biały przywołany jest w tekstach pt. Chwile grozy, Obłęd oraz Brama tęczy. Porównajmy: „to śmierć jej biel znów jest tak blisko” (Kreon, Chwile grozy); „biała jak śmierć meduza pośród tuneli żył” (Kreon, Obłęd); „Białą dłonią zamknie oczy” (Ceti, Brama tęczy); „zaklinam cię znów widzę twoich oczu biel / chłodną biel” (Kreon, Obłęd). Choć potocznie barwie BIAŁEJ przypisuje się dobro i czystość, Ryszard Tokarski udowadnia, że w tekstach poetyckich bywa zupełnie odwrotnie. BIELI może towarzyszyć konotacja smutku i śmierci [Tokarski 1996: 103; 1998: 16]. Potwierdzają to również słowniki symboli mówiące o żałobnej bieli w krajach Azji [zob. Simarro 2008: 19; Robakiewicz 2009: 29; Kopaliński 2012: 17]. Marzena Marczewska wymienia wśród określeń śmierci sformułowania „biała / ta bioło, bioło pani" [Marczewska 2011: 6]. Wchodząc w przestrzeń tekstów, dostrzegamy, że BIEL zestawiona ze śmiercią najczęściej przeraża, zwiastuje coś złego. Chłód, śnieg czy też bliskie konotacje z narkotykami w utworze Obłęd zespołu Kreon uzupełniają owo przekonanie. Jedynie w piosence Brama tęczy BIEL śmierci koi, uspokaja, jest czymś pożądanym. $Z$ drugiej strony śmierć wiąże się z CZERNIĄ. Porównajmy: „Już nadchodzi, zbliża się / Czarna śmieré” (Magnus, Czarny anioł); „Na pokładzie czarna śmierć / Matka Króla bez litości / Która zawsze przy nim jest” (Magnus, Czarny aniol); „Szatańska kawaleria - czarna śmierć!” (Turbo, Kawaleria Szatana cz. I); „Czarna śmierć zaciska kły” (Vader, Deathlike Carrion); „Śmierć, śmierć / Przeklęta czarna śmierć straconych dusz” (Vader, Deathlike Carrion). Choć 'czarna śmierć' zwykle oznacza 'dżumę' lub 'czarną ospę' [Kopaliński 2012: 419], trudno jest z kontekstu wywnioskować, czy autorzy mieli na myśli wyżej wymienione choroby, czy też kolor szat śmierci, jej twarzy itd. Niemniej CZERŃ idealnie współgra z nastrojem grozy. Możemy zatem stwierdzić, że zarówno BIEL, jak i CZERŃ łączy wspólna symbolika śmierci [Tokarski 1995: 53].

Śmierci od wieków przypisuje się różne ATRYBUTY. W badanych tekstach są nimi KOSA i KAPTUR. Oto przykłady: „Koniec jest bliski, nadchodzi śmierć / i tępa kosa ścina Twój łeb” (Aggressor, Aids\&China); „Kaptur, kosę ma / [...] / Jej twarz - grozy twarz” (Egzekuthor, Egzekutor); „Prędzej, prędzej dogonisz śmierć / Pod kaptur zajrzeć jej” (Azzaron, Szalony bieg). W słownikach symboli podkreśla się, że KOSA to nieodłączny rekwizyt śmierci, który służy nieodwracalnemu przecinaniu ludzkiego życia [zob. Simarro 2008: 112]. Obok wizerunku kościotrupa z KOSĄ i KAPTUREM, w średniowieczu śmierć wyobrażano sobie jako ,[...] uzbrojoną kobietę o skrzydłach nietoperza, pazurach jastrzębia i rozpuszczonych włosach" [Kopaliński 2012: 417]. Pewne podobieństwo do tej deskrypcji wykazuje opis Kali - hinduskiej bogini śmierci: Jej dtugie szpony jak szpony orła 
/ Wbite są w głą ciała próżni / Wciąż wyszarpuja serca galaktyk (Turbo, Bogini chaosu). Możemy zatem stwierdzić, że wymienione powyżej egzemplifikacje wpisują się w prototypowe, utrwalone kulturowo obrazowanie śmierci.

Następna faseta obejmuje CECHY i WŁAŚCIWOŚCI śmierci, a zatem odpowiada na pytanie, JAKA JEST ŚMIERĆ. Potraktujemy tę fasetę szeroko, wymieniając zarówno cechy charakteru uosobionej śmierci, jak i jej inne przymioty, które nie mieszczą się w wyglądzie zewnętrznym. Pojedyncze wskazania budują następujący obraz: śmierć jest SZYBKA i OKRUTNA: „Napadła cicha, szybka jak cień / Straszliwa zjawa, okrutna śmieré" (Azzaron, Dzień zagła$d y$ ); CHYTRA: „ciało trupa mota się - chytra śmierć” (Kreon, Czarny elf), a ponadto, abstrahując od jej postępowania, jest TOTALNA: „Trzeba zabić bestię, to bestii śmiech, / Rodzi ból bez końca, totalną śmierć" (Oddech Buntownika, Krew i tzy); WIECZNA: „Bramy piekieł, królestwo złego, ognista otchłań, gdzie wieczna śmierć!” (Vader, Deathlike Carrion) i PRZEKLĘTA: „Śmierć, śmierć / Przeklęta czarna śmieré straconych dusz" (Vader, Deathlike Carrion). Podane jednostki znaczeniowe charakteryzują śmierć jako postać, która przychodzi nagle i pozbawia człowieka życia bez względu na wszystko. O jej uniwersalizmie świadczy stwierdzenie, że jest WIECZNA.

Kolejną fasetę stanowią CZYNNOŚCI ŚMIERCI, w tym także relacje ŚMIERĆ - CZŁOWIEK. Jedną z wykonywanych przez nią czynności jest straszenie ludzi poprzez nagłe WYCHODZENIE ZE SWYCH KRYJÓWEK. Porównajmy: „Tkwi zakopana gdzieś przez całe lata śmierć / Ukryta w ścianach skrzyń czeka dnia aby wyjśćc” (Alastor, Dotyk przemocy); „Opuszcza swój grób” (Egzekuthor, Egzekutor); „Po drugiej stronie tego świata budzi się śmierć, przemoc i gwałt” (Oddech Buntownika, Ostatni dzień przed zmartwychwstaniem); „Z otchłani piekła żywa śmierć wyciąga dłoń swą i szepcze Chodž!!!" (Oddech Buntownika, Już tu nie wrócisz szatanie). Kryjówką śmierci może być zatem grób bądź wymiar pozaziemski, np. piekło. Szczególnie częste jest wskazywanie na ZBLIŻANIE SIĘ bądź na NADCHODZENIE śmierci: „Śmierć nadchodzi, powoli zbliża się” (Hellias, Noc potęienia); „Śmierć czai się” (Magnus, Miasto zła); „W domu twym śmierci jest siedlisko / porzuć strach ona jest już blisko" (Kreon, Śmierć); „Śmierć czeka na wszystkich, / Na wszystkich czeka śmierć, / Śmierć czeka na wszystkich / I wszyscy czekają jej” (Oddech Buntownika, Krew i łzy); „Wszędzie czeka cię śmieré" (Thrasher Death, Ave Destruction). Gdy śmierć jest już blisko człowieka, OBJAWIA mu SIĘ. Na przykład: „Życie, pozbawią go nas / Śmieré, ukaże się nam” (Azzaron, Otchłań zła); „Czcicieli innej wiary w lochach witała śmierć” (Destroyers, Młot na Święta Inkwizycję). Zaczepia człowieka, próbuje nawiązać z nim KONTAKT SŁOWNY. Porównajmy: „Nad bramą grobu zawisł cień. / - Ej! / - Ty kto? / - Śmierć” (KAT, Porwany obłędem); ,Z otchłani piekła żywa śmierć wyciąga dłoń swą i szepcze Chodž!!!" (Oddech Buntownika, Już tu nie wrócisz szatanie). 
Spotkanie ze śmiercią nigdy nie jest przypadkowe. Przybywa bowiem w konkretnym celu - aby ZABRAĆ CZŁOWIEKOWI ŻYCIE. Eksploracja korpusu tekstowego odsłania prawdziwe bogactwo językowe w obrębie tego pola leksykalno-semantycznego. Tak więc, śmierć może pozbawiać człowieka życia poprzez ZABIERANIE: „Kres dni, życia blask / Podlega to pod nią / [...] / Zabieranie życia starcom / Dzieciom kiedy czas / Ich godzinę ona dobrze zna / Biednym i bogatym, mądrym, głupim, dobrym, złym / Sprawiedliwa ręka nie da szans” (Egzekuthor, Egzekutor); „Wszystko to co mamy / Zabiera śmierć” (Quo Vadis, [...] Albo nie być); ZBIERANIE PLONÓW / ZBIERANIE HARACZU: „Znam ten dom z opowiadania złych / Wiem jak śmierć haracz zbiera z krwi” (Egzekuthor, Śmierci i władzy pakt); „śmierć jest jak apostoł zjawia się zbiera swój plon” (Kreon, Śmierć); „[...] śmierć cieszy się. / Dziś zbierze plon w tysiącach ton” (Wilczy Pająk, Groźba), POCHŁANIANIE: „śmierć pochlania ludzi jest gdzieś obok nas” (Kreon, Śmierć), DOPADANIE: „Śmierć dopadła Cię, to koniec jest” (Stos, Ostatni dreszcz); „W czterech ścianach własnych marzeń / Dopadnie cię śmierć..." (TSA, Biała śmierć) i WCHODZENIE W CIAŁO: „Ciała twych wrogów, rozdarte przez miecz / Będą się wiły, nim wejdzie w nie śmierć" (Thrasher Death, Czarny Aniot). Do eufemizmów opisujących działanie śmierci można zaliczyć czasownik OTULAĆ, por.: „Białą dłonią zamknie oczy / I otuli płaszczem snów" (Ceti, Brama tęczy). Odbieranie człowiekowi życia jest uniwersalne, śmierć nie patrzy bowiem na majętność swej ofiary, jej wiek i status społeczny. Stąd też wniosek, że ZRÓWNUJE ludzi: „Kiedy śmierć zrówna nas / Spotkasz mnie w piekle" (Destroyers, Młot na Święta Inkwizycję). Pozbawianie życia sprawia śmierci wielką radość, o czym informuje nas jej złowieszczy ŚMIECH: „Na szafot prowadzą moje życie / Widzę jak śmierć śmieje się” (Quo Vadis, Szafot); „Zaczęło się, śmierć cieszy się. / Dziś zbierze plon w tysiącach ton" (Wilczy Pająk, Groźba). Ostatecznie, ludziom pozostaje wiara w to, że śmierć PRZEMIJA: ,śmierć przemija w zapomnienie / Bo życie to wielkie przedstawienie" (Oddech Buntownika, Oddech Buntownika). Wyobrażenia metalowców pokrywają się w dużej mierze z potoczną konceptualizacją śmierci, tym samym potwierdzając tezę, że teksty o proweniencji artystycznej stanowią istotne źródło rekonstrukcji językowego obrazu świata. W języku potocznym utrwalone są frazeologizmy „zabierać życie” czy „kogoś dopadła śmierć”. Działania śmierci podobnie ujmuje literatura. W Słowniku symboli nietrudno odnaleźć cytaty z reprezentatywnych dzieł literackich, w których śmierć jest ŻNIWIARZEM i ZŁODZIEJEM, ale i swoistym DAREM [zob. Kopaliński 2012: 416, 418].

Z omówioną powyżej fasetą wiąże się następna, opisująca relacje CZŁOWIEK - ŚMIERĆ. Obrazuje ona kontakty ludzi ze śmiercią, ich podejście do niej, oczekiwania. Najpierw omówmy relacje pozytywne. Metalowcy opisują śmierć w swych tekstach jako istotę, na którą OCZEKUJĄ: ,dalej już nie masz sił / śmierci chcesz” (Kreon, Rok 3030); „Jestem w ciszy oczekuję na przyjście śmierci mej” (Kreon, Przeznaczenie); „Śmierć czeka na wszystkich / I wszyscy czekają 
jej” (Oddech Buntownika, Krew i łzy). Wynika z tego, że NIE NALEŻY SIĘ JEJ BAĆ, co dotyczy przede wszystkim dzielnych wojowników: „Nie boją się / Nie straszna im śmierć" (Hellias, Bitwa). W najgorszych chwilach to ona jest LEKARSTWEM: „Ślepej miłości prysnął czar / Zdradzony, śmiercią chcesz uśmierzyć ból" (Destroyers, Wino i sex). Możliwe jest DOGADANIE SIĘ ze śmiercią, jak z kimś bliskim, wobec czego nie przychodzi nieproszona: „Dogadalem się ze śmiercią / Na wezwanie przyjdzie tu / Białą dłonią zamknie oczy / I otuli płaszczem snów" (Ceti, Brama tęczy). Staje się na tyle bliska, że osoba mówiąca chce z nią PRZEBYWAĆ, w piekielno-mrocznym anturażu: „Razem ze śmiercią gorącą krew nocą pić" (Vader, Tyrants of Hell). W niektórych cytatach urasta do rangi WARTOŚCI. Możemy odczuć jej sens i dostrzec bezcenny charakter: „odczułem prawdę jego słów, poczułem śmierci sens” (Kreon, Kapłan); „Jeśli chcesz kupić świat - kupisz go. / Możesz mieć władzę, tron, królestwo swe. / Wszystko to możesz mieć, gdy złoto masz. / Tylko śmierć oprze się - nie kupisz jej" (Wilczy Pająk, Memento Mori). Z drugiej strony śmierć wciąż jest zjawiskiem wzbudzającym lęk, co owocuje negatywnymi relacjami „,człowiek - śmierć”. Odwieczna próba uniknięcia jej wywołuje pragnienie OSZUKANIA: „Oszukać śmierć, / przechytrzyć własny los” (Ceti, Ogień i łzy). Poprzez zjedzenie bądź wyplucie opisuje się chęć POKONANIA śmierci: „Gdy zjem już wszystko, pożrę swoją śmierć!” (TSA, Jestem głodny); „Wyplułem śmierć” (KAT, Wyrocznia). Choć chcemy ją DOGONIĆ, to najprawdopodobniej ona dogoni nas i zabije: „Prędzej, prędzej dogonisz śmierć / Pod kaptur zajrzeć jej” (Azzaron, Szalony bieg).

Różne właściwości śmierci, na które wskazują wyodrębnione fasety, przyczyniają się do zbudowania całościowej ramy interpretacyjnej. Na śmierć należy patrzeć przez pryzmat kultury, która wpływa na jej konceptualizację w badanym materiale. Z poszczególnych faset wynika, że, wyobrażając sobie śmierć jako istotę przyodzianą w kaptur i dzierżącą kosę, metalowcy utrwalają ukuty przed wiekami stereotypowy bądź prototypowy obraz śmierci. Opisywana bywa jako przeraźliwy stwór, który wzbudza lęk u człowieka i ma nad nim władzę. Na tę właściwość śmierci wskazuje szereg połączeń wyrazowych. Jej okrucieństwo i nieuchronność, przypisywane od wieków atrybuty i wygląd to tylko niektóre cechy składające się na prototypowe jądro leksemu ŚMIERĆ, budowane przez pryzmat analizowanych tekstów. Z kolei jej pozytywne relacje z człowiekiem, w tym dawanie mu ukojenia, chęć bliskości, moglibyśmy instynktownie zakwalifikować do cech bliższych peryferiom, a w konsekwencji - do konotacji słabych. Odwołując się jednak do kultury, a konkretnie do Pisma Świętego, widzimy, że człowiek biblijny boi się śmierci, ucieka przed nią, ale jednocześnie kocha ją i traktuje jak swoją przyjaciółkę. Co więcej, nieraz uważa ją za coś lepszego od życia, prosi o nią, czeka na nią, a czasem nawet się jej domaga [Herej-Szymańska 2004]. Możemy zatem dojść do wniosku, że zarówno pozytywny, jak i negatywny stosunek do śmierci, który kreują metalowcy, ma podłoże kulturowe, a wiele poetyckich skojarzeń tkwi głęboko w języku i kulturze. 


\section{Bibliografia}

Bartmiński J. (red.) [1996], Stownik stereotypów i symboli ludowych, t. 1, cz. 1: Kosmos. 1, Niebo, światta niebieskie, ogień, kamienie. Koncepcja całości, Wydawnictwo Uniwersytetu Marii Curie-Skłodowskiej, Lublin.

Grzegorczykowa R. [2004], Pojęcie językowego obrazu świata, [w:] J. Bartmiński (red.), Językowy obraz świata, Wydawnictwo Uniwersytetu Marii Curie-Skłodowskiej, Lublin, s. 39-46.

Herej-Szymańska K. [2004], Biblijny obraz językowy stosunku człowieka do śmierci, „Język Polski”, nr 3, s. 164-173.

Kopaliński W. [2012], Stownik symboli, Oficyna Wydawnicza RYTM, Warszawa.

Marczewska M. [2011], Oswajanie śmierci stowem - o śmierci w kulturze, języku i wybranych tekstach Jana Pawta II, http://marzenamarczewska.pl/wp-content/uploads/2011/04/Marczewska-Marzena-Papiezla.pdf

Pęczak M. [1992], Mały słownik subkultur młodzieżowych, Wydawnictwo SEMPER, Warszawa.

Prejs B. [2005], Subkultury młodzieżowe. Bunt nie przemija, Wydawnictwo KOS, Katowice.

Robakiewicz L. (red.) [2009], Leksykon symboli. Herder, przeł. J. Prokopiuk, Dom Wydawniczy tCHu, Warszawa.

Simarro A.S. [2008], Słownik symboli, z hiszp. przeł. M. Boberska, Wydawnictwo ŚWIAT KSIĄŻKI, Warszawa.

Tokarski R. [1995], Semantyka barw we współczesnej polszczyźnie, Wydawnictwo Uniwersytetu Marii Curie-Skłodowskiej, Lublin.

Tokarski R. [1996], Ramy interpretacyjne a problemy kategoryzacji. (Przyczynek do tak zwanej definicji kognitywnej), [w:] R. Grzegorczykowa, A. Pajdzińska (red.), Językowa kategoryzacja świata, Wydawnictwo Uniwersytetu Marii Curie-Skłodowskiej, Lublin, s. 97-112.

Tokarski R. [1998], Językowy obraz świata a niektóre założenia kognitywizmu, „Etnolingwistyka. Problemy języka i kultury”, nr 9/10, J. Bartmiński (red.), Lublin, s. 7-23.

Zawadzki M. [2005], Komunikacja werbalna i niewerbalna subkultury satanistów i metalowców. Podobieństwa i różnice obu grup, [w:] Z. Pasek (red.), Ezoteryzm, okultyzm, satanizm w Polsce, Wydawnictwo LIBRON, Kraków, s. 181-195. 